\title{
About Birds near Mt. Kinabalu in Borneo
}

\author{
Tadayuki Miyamoto
}

要 約 - 宮本忠 飞

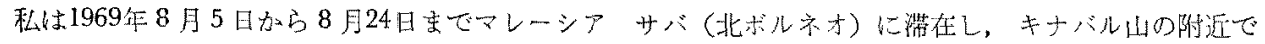

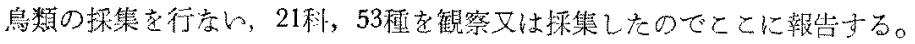

From August 5 to 24 in 1969, I made a small expedition in company with Mr. Tanaka, Professor of Yamate Women's College who collected butterflies. As I collected or observed 53 species of birds near Mt. Kinabalu, I am going to inform the results of my trip.

Expecting to get lowland species, submontane species and shore species, headquarters in Borneo were

1. From Aug. 8 to 13 in Kota Belud.

2. From Aug. 14 to 16 in Kundasang.

3. From Aug. 17 to 23 in Papar.

1. Pandasan, about half an hour's distance from Kota Belud by jeep, is one of the best places to observe and to collect birds. There were lovely woods and streams, and the number and species of birds abundant.

There were many Doves and Pigeons, Bulbuls, Drongos, Leafbirds, Kingfishers, Flowerpeckers, Sunbirds, Flycatchers, Cuckoos, and etc.

2. Kundasang, at the halfway of Mt. Kinabalu, is a cool and comfortable place being about 5000 feet above sea level. I heard that this area was one of the best places to observe submontane species of birds.

But so far as this season was concerned, the number of birds was rather few. I could collect some submontane species though.

3. Papar, near seashore, is situated about 15 miles south from Kota Kinabalu, and is the place having moderate woods and several ponds. In the other seasons large number of Plovers and Snipes are to assemble on this seashore. But in this season only a small number of them were dotted.

Over much of this range birds were found in large numbers, but the species of ones were rather few.

In Papar White collored Kingfishers were conspicuously many, and also various kinds of Sunbirds and White-bellied Swiftlets were many. Tailorbirds and Fantail Flycatchers could be found in large numbers, too.

I went to Java in 1961, Formosa in 1967, and India in 1968 for the purpose of 
collecting birds. As compared with those areas, I couldn't even catch a glimpse of Barbets and Woodpeckers which I had expected to observe. Of couse Tree Sparrows or House Sparrows were not seen, but I could see a lot of Munias that fed on grains of rice. I could hardly see Ground Thrushes. Drongos were very few. But Cuckoos, White breasted Waterhens, Spotted-necked Doves, and Tailor Birds were seen in large numbers in these areas.

Mr. Tsen, a subcurator of the Sabah Museum, collected White Ground Thrush (Zoothera dauma) in Mantanani island near Borneo during our trip. This Thrush is a new recoad in Borneo. As I brought back this specimen to Japan, I will explain about it later.

I got about 130 birds in Borneo, and some of them were left behind to the Sabah Museum.

Next I am going to discourse upon the species that I brought back to Japan, and the birds whose existence I confirmed only by the observation of them.

During our trip to Borneo, I was offered a great help by the Sabah Museum. Especially Mr. Pike, a curator of the Museum, took pains for the arrangment of our various programs. I am very thankful to him and Museum's staff for the many kindness that given to us. In Japan I was given advice about identification of my collected birds from Mr. Kobayashi. I would like to express my hearty thanks to him too.

(N. B.)

I. * : Birds confirmed by only witness.

2. non * : Birds collected.

3. Birds collected are to be used a trinomial.

4. Birds confirmed by only witness are to be used a binomial.

$$
\text { Family Ardeidae }
$$

* 1. Ixobrychus cinnamomeus (Gmelin) Papar

(Note) I often observed the birds near ponds in Papar. The habits are similar to I. sinensis in Japan.

(Distribution) Eastern Asia from China south to the Philippines and Sunda Islands, west to India.

Fanity Accipitridae

* 2. Haliastur indus (Boddaert) Papar

(Note) I observed the birds flying round Papar's seacoast several times.

(Distribution) From West Pakistan east to Southern China, and south through the Malaysian subregions and Philippines to Australia.

\section{Family Rallidae}

* 3. Amaurornis phoenicurus (Pennant) Kota Belud, Pandasan, Papar

(Note) I often met the birds running across our jeep or walking in gutters. 
(Distribution) India, the Indochinese and Malaysian subregions and Indonesian Islands, and Philippines.

\section{Family Charadriidae}

4. Charadrius peronii Schlegel 1ㅇ, Aug. 20 Papar

(Note) I observed the birds dotted on Papar's seacoast. Iris dark brown, feet pale leaden, bill black, lower's base pale leaden. Culmen $17 \mathrm{~mm}$, wing $93 \mathrm{~mm}$, tail $51 \mathrm{~mm}$, tarsus $29 \mathrm{~mm}$.

(Distribution) The Philippines, Borneo, Java, Lesser Sunda Islands and Celebes.

5. Charadrius leschenaultii leschenaultii Lesson 1ㅇ, Aug. 20, Papar

(Note) The birds were seen on Papar's seacoast. The habits are similiar to the other Plovers. Iris dark brown, bill black, feet dark green. Culmen 23mm, wing $142 \mathrm{~mm}$, tail $68 \mathrm{~mm}$, tarsus $34 \mathrm{~mm}$.

(Distribution) Breeds in northern Asia, wintering to south Africa, southern Asia, Australia, and the Solomon Islands.

\section{Family Scolopacidae}

6. Tringa hypoleucos hypoleucos Linnaeus 1, Aug. 20, Papar

(Note) I often observed the birds on the seacoast and near ponds in Papar. Iris dark brown, feet greenish yellow, bill bark brown above, rather greenish below. Culmen $25 \mathrm{~mm}$, wing $106 \mathrm{~mm}$, tail $63 \mathrm{~mm}$, tarsus $25 \mathrm{~mm}$.

(Distribution) A palaearctic breeding species, wintering in southern Europe, Africa, southern Asia, Philippines, and Australia.

\section{Family Columbidae}

7. Treron olax arismicra Oberholser 1우, Aug. 9, Pandasan

(Note) In Pandasan the birds were sometimes observed in groups. Iris brown outside, pale bluish green inside, feet light red, bill bluish green, the tips of bills rather pale. Culmen $16 \mathrm{~mm}$, wing $119 \mathrm{~mm}$, tail $124 \mathrm{~mm}$, tarsus $13 \mathrm{~mm}$.

(Distribution) Northern Borneo

8. Streptopelia chinensis tigrina (Temmink) 1\$, Aug. 9, Pandasan

(Note) I observed the birds more on the trees near country houses than in jungles. The birds were often seen everywhere. I give the specimen to Sabah Museum, for it was protected by law.

(Distribution) East Pakistan east to Burma, Borneo, and Sunda Islands from Sumatra to Bahar.

9. Chalcophaps indica indica (Linnaeus) 1to, Aug. 11, Pandasan

(Note) I observed the birds only twice, though they are rather common. I gave the specimen to the Museum by same reason former.

(Distribution) India, East Pakistan, the Philippines, Borneo and Celebes to the Greater Sunda Islands, and Lesser Sunda chain to Alor and Sumba.

Family Cuculidae

$$
\text { (3) }
$$


10. Cacomantis sonneratii schlegeli (Junge) 1古, Aug. 10, Pandasan

(Note) I couldn't see the species at all, but I got this one by a mist net. Iris dark brown, feet yellow, bill black above, dark red below. Culmen $19 \mathrm{~mm}$, wing $97 \mathrm{~mm}$, tail $116 \mathrm{~mm}$, tarsus $15 \mathrm{~mm}$.

(Distribution) S. E. Asia

11. Cacomantis merulinus threnodes Cabanis \& Heine 1§, Aug. 20, Papar

(Note) I often saw this species in Paper, but could hardly sce in other areas. Bill dark brown, iris red, feet palc brown, claws black. Culmen $20 \mathrm{~mm}$, wing $103 \mathrm{~mm}$, tail $104 \mathrm{~mm}$, tarsus $14 \mathrm{~mm}$.

(Distribution) Malay states (Except northern part), Sumatra, Siberut, Fngano, and Borneo

*12. Centropus sinensis (Stephens) Pandasan, Poring, Papar

(Note) Very common in open country and in jungle.

(Distribution) From India to Southern China, Indochinese and Malaysian subregions, and Philippines.

\section{Family Caprimulgidae}

13. Caprimulgus macrurus salvadori Sharpe 1 sex unknown, Aug. 20, Papar

(Note) I observed the birds often in Papar and once in Pandasan. The habits are similar to $\mathrm{C}$. indicus in Japan. Iris dark brown, feet dark brown above, brown below. Culmen $12 \mathrm{~mm}$, wing $186 \mathrm{~mm}$, tail $142 \mathrm{~mm}$, tarsus $15 \mathrm{~mm}$.

(Distribution) Borneo and Palawan.

\section{Family Apodidae}

14. Collocalia esculenta cyanoptila Oberholser 1今, Aug. 19, Papar

(Note) Common in Papar both the seacoast and in the towns. Iris dark brown, feet and bill black. Culmen $4 \mathrm{~mm}$, wing $98 \mathrm{~mm}$, tail $45 \mathrm{~mm}$, tarsus $7 \mathrm{~mm}$.

(Distribution) Malay States, Lingga Archipelago, eastern Sumatra, Billiton, Natuna Islands and lowland of Borneo.

*15. Apus affinis (J. E. Gray)

(Note) I observed the birds flying to and fro under the floors of the houses on the water in Kota Kinabalu.

(Distribution) Africa, India through the Indochinese and Malaysian subregions to Philippines, south china and Formosa.

\section{Family Alcedinidae}

16. Halcyon chloris laubmanniana Grote 1今, 1우, Aug. 18, 21, Papar

(Note) I saw the birds three times in Kota Belud, and about 50 in Papar. Noisy on the top of the trees. Iris dark brown, feet dark brown, bill black above, black at the tip cream at the base below, Culmen $47,41 \mathrm{~mm}$, wing $110,104 \mathrm{~mm}$, tail 74 , $77 \mathrm{~mm}$, tarsus $12,10 \mathrm{~mm}$.

(Distribution) Anamba Islands, North and South Natuna Islands, North Bornean 
Islands, Borneo, southern and southeastern Sumatra, Rhio and Lingga Archipelagos, Banka, Billiton.

*17. Pelargopsis capensis (Linnaeus) Papar

(Note) I observed the bird flying through the jungle in Papar once for all. (Distribution) India, S. E. Asia

18. Alceco meninting verreaxi De La Berge If, 1 sex unknown Aug. 20, Papar (Note) Sometimes I observed the birds in Pandasan and Papar. Not so rare. Iris dark brown, feet scarlet, bill black above, reddish brown below. Culmen 33, $36 \mathrm{~mm}$, wing $60,69 \mathrm{~mm}$, tail $34,42 \mathrm{~mm}$, tarsus 7, $8 \mathrm{~mm}$.

(Distribution) Malay Peninsula, Sumatra, Rhio Archipelago, Banka, Billiton and Borneo.

*19. Ceyx erithacus (Linnaeus)

Pardasan

(Note) I observed the bird only once in woods along the stream in Pandasan.

(Distribution) S. E. Asia

Family Pittidae

*20. Pitta baudi muller \& Schlegel

Pandasan

(Note) I got the bird by a mist net, but unfortunately I missed it.

(Distribution) Confined to Borneo.

Family Campephagidae

21. Lalage nigra nigra (Forster) 10ิ, 19, Aug. 17, 19, Papar

(Note) Sometimes I observed the birds in the jungle near the seacoast of Papar.

Iris dark brown, feet black, bill black but dark brown at the base below. Culmen 15 , $14 \mathrm{~mm}$, wing $96,95 \mathrm{~mm}$, tail $82,83 \mathrm{~mm}$, tarsus $22,19 \mathrm{~mm}$.

(Distribution) Malay Pcninsula, Sumatra, Java, Nias, Karimundjawa Island, and Borneo.

\section{Family Artamidae}

22. Artamus leucorhynchus leucorhynchus (Linnaeus) 1\$, Aug. 17, Papar

(Note) This birds can not be rare, but I could not see the one at all. I got it by a mist net. Iris dark brown, feet leaden, bill pale leaden blue. Culmen $22 \mathrm{~mm}$, wing $134 \mathrm{~mm}$, tail $75 \mathrm{~mm}$, tarsus $15 \mathrm{~mm}$.

(Distribution) Philippines and Malaysia to Australia and Fiji.

\section{Family Irenidae}

23. Aegithina tiphia aequanimis Bangs 1\}, Aug. 19, Papar

(Note) I could often observed the birds both in jungle and in the woods near the houses. Iris pale yellow, feet pale leaden, bill black above, leaden below. Culmen $17 \mathrm{~mm}$, wing $63 \mathrm{~mm}$, tail $51 \mathrm{~mm}$, tarsus $19 \mathrm{~mm}$

(Distribution) N. Borneo and neighboring Islands.

*24. Irena puella (Latham)

Pandasan

(Note) Only once I could observe this famous bird flying about in Pandasan's 
jungle.

(Distribution) A. E. Asia

Family Pycnonotidae

25. Pycnonotus zeylanicus (Gmelin) 1古, Aug. 15, Kundasan

(Note) Observing this species only once in Kundasan, I collected that one. Iris brown, feet and bill dark brown. Culmen $19 \mathrm{~mm}$, wing $122 \mathrm{~mm}$, tail $112 \mathrm{~mm}$, tarsus $21 \mathrm{~mm}$.

(Distribution) Malay Peninsula, Sumatra, Java, and Borneo.

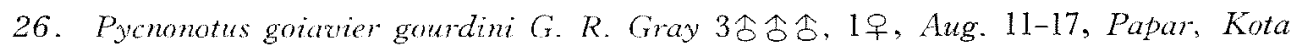
Belud, Kundasang.

(Note) Very common everywhere from lowland to high mountains. Iris dark brown, feet and bill black. Culmen 17, 17, 17, 16mm, wing 90, 88, 87, 84mm, tail 92, 91, 87, 85mm, tarsus 19, 19, 19, 17mm.

(Distribution) Borneo and Maratua Islands.

27. Pycnonotus plumosus insularis Chasen \& Kloss 2古古, 1우, Aug. 9-10, Pandasan, Kota Belud.

(Note) Very common in the jungle of lowland. Iris grape red, feet brown, bill black. Culmen $16,16,16 \mathrm{~mm}$, wing $89,86,89 \mathrm{~mm}$, tail $85,84,76 \mathrm{~mm}$, tarsus 17,16 , $17 \mathrm{~mm}$.

(Distribution) N. Borneo

28. Criniger phacocephalus sulphuratus Bonaparte 1f, Aug. 10, Pandasan

(Note) This species are common, but I saw only two beings in Pandasan's jungle. Iris reddish brown, feet pale brown, bill black avove, leaden below. Bill $20 \mathrm{~mm}$, wing $110 \mathrm{~mm}$, tail $91 \mathrm{~mm}$, culmen $18 \mathrm{~mm}$.

(Distribution) Malaysia

Family Muscicapidae

29. Copsychus saularis adamsi Elliot 1\}, 1우, Aug. 8, 12, Kota Belud

(Note) They were seen both in jungle and in the garden of our lodging house, and always sang sweetly. Iris dark brown, feet blackish brown, bill black. Culmen 23, 22mm, wing $114,104 \mathrm{~mm}$, tail $114,103 \mathrm{~mm}$, tarsus $32,30 \mathrm{~mm}$.

(Distribution) Brunei, E. Sarawak, N. Borneo, Banguey, Balembangan, Mallewalle and Sibatik Is.

30. Copsychus stricklandii stricklandii Motley \& Dillwyn 1今, Aug. 9, Pandasan

(Note) As compared with other races, its white crown is remarkable. And rather few in Sabah. Iris dark brown, feet pale brown, bill black. Culmen $19 \mathrm{~mm}$, wing $104 \mathrm{~mm}$, tail $132 \mathrm{~mm}$, tarsus $23 \mathrm{~mm}$.

(Distribution) India, S. E. Asia.

31. Zoothera dauma (Latham) 1 sex unknown, Aug. 12, Mantanani Is

(Note) This species had been observed through all over the Oriental Area except 
Borneo till now. Mr. Tsen, sub-curator of the Museum, collected this one in Mantanani Island near Borneo at August 12, 1969. Culmen 24mm, wing $156 \mathrm{~mm}$, tail $113 \mathrm{~mm}$, tarsus $32 \mathrm{~mm}$.

(Distribution) A palaearctic species breeding in the district from western Sibcria to Lake Baikal, the Amur River and the Maritime provinces, Japan, the Riukiu Is, W. Pakistan, India, Ceylon, Burma, the northern Indochinese subregion, Java, Bali, New Guinea, Australia and Tasmania. Vagrant in Europe. Wintering in the Indochinese subregion and Philippines.

32. Trichastoma rostratum macropterum (Salvadori) 1\}, Aug. 9, Pandasan

(Note) I observed the birds twice in Pandasan's jungle near a stream. Iris brown, feet leaden, bill black above, leaden below. Culmen $19 \mathrm{~mm}$, wing $72 \mathrm{~mm}$, tail $57 \mathrm{~mm}$, tarsus $24 \mathrm{~mm}$.

(Distribution) Borneo and Banggi.

33. Macronous gularis montanus (Sharpe) 2今ㅇ, 1우, Aug. 8-18, Kota Belud, Papar (Note) Very common everywhere. Iris pale lemon-yellow, feet greenish leaden or dark bone color, bill black above, leaden below. Culmen 14, 14, 14mm, wing 69, $65,65 \mathrm{~mm}$, tail $66,63,61 \mathrm{~mm}$, tarsus $24,22,21 \mathrm{~mm}$.

(Distribution) N. Borneo

34. Seicercus superciliaris schwaneri (Blyth) 1\}, Aug. 22, Papar

(Note) This species is one of submontane residents. But I got this bird in jungle of Panar (at within 5 feet above sca lcvel). Iris red, feet pale reddish brown, bill black. Culmen $17 \mathrm{~mm}$, wing $47 \mathrm{~mm}$, tail $61 \mathrm{~mm}$, tarsus $21 \mathrm{~mm}$.

(Distribution) S. E. Asia

35. Orthotomus sericeus sericeus Temmink 3今占, Aug. 9-12, Kota Belud, Pandasan (Note) Very common everywhere. Iris brown, feet pale brown, bill dark brown above, pale brown below. Culmen $17,17,16 \mathrm{~mm}$, wing 52, 52, 52mm, tail 47, 46, $47 \mathrm{~mm}$, tarsus $21,21,22 \mathrm{~mm}$.

(Distribution) Borneo

36. Orthotomus sepium borneonensis Salvadori 1今, Aug. 9, Pandasan

(Note) Common, but not as common as $O$. sericeus. Iris pale brown, feet brown bill black above, pale brown below. Culmen $15 \mathrm{~mm}$, wing $46 \mathrm{~mm}$, tail $45 \mathrm{~mm}$, tarsus $17 \mathrm{~mm}$.

(Distribution) Malaysia

37. Phipidura javanica longicauda Wallace 2今方, Aug. 8, 17, Kota Belud, Papar (Note) Very common everywhere. They are by no means shy but boldly enter gardens. Iris dark brown, feet and bill dark brown. Culmen 13, 12mm, wing 126, $129 \mathrm{~mm}$, tail $144,150 \mathrm{~mm}$, tarsus $15,17 \mathrm{~mm}$.

(Distribution) Malaysia

38. Muscicapa venusta Deignan 1, Aug. 9, Pandasan 
(Note) I couldn't observe this bird, but collected this one by a mist net. Iris dark brown, feet leaden bone, bill black. Culmen $13 \mathrm{~mm}$, wing $73 \mathrm{~mm}$, tail $58 \mathrm{~mm}$, tarsus $15 \mathrm{~mm}$.

(Distribution) Confined to Borneo

39. Muscicapa turcosa rupatensis Oberholser 11. Aug. 10, Pandasan

(Note) I saw this species only once in the jungle of Pandasan, and collected that one. There were various Blue Flycatchers in Borneo, so it was difficult to distinguish them in the field. Iris dark brown, feet leaden black, bill black. Culmen $14 \mathrm{~mm}$, wing $80 \mathrm{~mm}$, tail $66 \mathrm{~mm}$, tarsus $16 \mathrm{~mm}$.

(Distribution) Malaya, Sumatra, Borneo.

40. Muscicapa rufigastra nufigastra Raffles 1 sex unknown, Aug. 11, Kota Belud

(Note) I couldn't observe this bird anywhere, but collected this one by a mist net.

Iris brown, feet blackish brown, bill black. Culmen $12 \mathrm{~mm}$, wing $74 \mathrm{~mm}$, tail $6 \mathrm{lmm}$, tarsus $17 \mathrm{~mm}$.

(Distribution) Borneo, the northern Borneo Islands and Maratuas

41. Rhinomyias olivacea olivacea (Hnme) 15, Aug. 11, Kota Belud

(Note) I couldn't observe this bird, but collected this one by a mist net. Iris dark red, feet leaden, bill black. Culmen $13 \mathrm{~mm}$, wing $79 \mathrm{~mm}$, tail $68 \mathrm{~mm}$, tarsus $17 \mathrm{~mm}$.

(Distribution) N. Natunas, N. Borneo.

Family Dicaeidae

42. Dicaeum cruentatum nigrimentum Salvadori 2今令, 1ㅇ, Aug. 17-23, Papar

(Note) Common in the jungle of Papar. Iris dark brown, feet and bill black. Culmen 10, 9, 10mm, wing 47, 48, 46mm, tail 29, 31, 28mm, tarsus $11,11,10 \mathrm{~mm}$.

(Distribution) Karimata Islands and Borneo.

43. Dicaeum trigonostigma dayakanum Chasen \& Kloss 1\$, Aug. 9, Pandasan

(Note) I observed the bird only once, and collected this one. Iris dark brown, feet and bill black. Culmen $10 \mathrm{~mm}$, wing $55 \mathrm{~mm}$, tail $31 \mathrm{~m} \mathrm{n}$ tars $13 \mathrm{~s} 13 \mathrm{~mm}$.

(Distribution) Borneo and northern Bornean Islands.

Family Nectariniidae

44. Anthreptes malacensis borneensis Riley 1\}, 1우, Aug. 17, 19, Papar

(Note) Common in the jungle of Paper. Iris red, feet dark brown, bill black above, pale below. Culmen $16,16 \mathrm{~mm}$, wing $68,66 \mathrm{~mm}$, tail $55,51 \mathrm{~mm}$, tarsus 18 , $15 \mathrm{~mm}$.

(Distribution) N. Borneo, northern Bornean Islands, Mangalum Island.

45. Hypogramma hypogrammicum hypogrammicum Muller 1\}, Aug. 9, Pandasan

(Note) I could observe this species only once in spite of being common. Iris dark red, feet yellow, bill black. Culmen $22 \mathrm{~mm}$, wing $69 \mathrm{~mm}$, tarsus $15 \mathrm{~mm}$.

(Distribution) Sumatra and Borneo. 
46. Nectarinia chalcostetha Jardine 1, 1우, Aug. 19, 20, Papar

(Note) Common in the jungle of Papar. Iris and feet dark brown, bill black.

Culmen $17,19 \mathrm{~mm}$, wing $49,52 \mathrm{~mm}$, tail $38,39 \mathrm{~mm}$, tarsus $12,11 \mathrm{~mm}$.

(Distribution) Malaysia, Celebes

47. Nectarinia jugularis ornata (Lesson) 1우, Aug. 9, Pandasan

(Note) Common in the jungle of Pandasan. Iris and feet dark brown, bill black.

Culmen $15 \mathrm{~mm}$, wing $45 \mathrm{~mm}$, tail $36 \mathrm{~mm}$, tarsus $11 \mathrm{~mm}$.

(Distribution) S. E. Asia

*48. Aethopyga mystacalis temminckii (Muller) Kota Belud

(Note) I observed two birds carrying materials for their nest on a tree.

(Distribution) Extreme southern Peninsular Tailand south to Malay Peninsula,

Sumatra and Borneo.

Family Ploceidae

49. Lonchura fuscans (Cassin) 1今, 1우, Aug. 20, 22, Papar

(Note) Abundant in open country. Iris dark brown, feet black, bill black above, leaden below. Culmen $11,11 \mathrm{~mm}$, wing $52,49 \mathrm{~mm}$, tail $47,46 \mathrm{~mm}$, tarsus $16,13 \mathrm{~mm}$.

(Distribution) Borneo and Natuna, Cagayan Sulu, and Banguey Islands.

50. Lonchura malaca jagori (Von Martens) 2우, 2§\}, Aug. 18-21, Papar

(Note) Abundant in open country. Iris dark brown, feet leaden, bill pale leaden.

Culmen 10, 10, 11, 10mm, wing 54,51, 52, 52mm, tail 43, 41, 46, 46mm, tarsus 11 , $12,13,12 \mathrm{~mm}$.

(Distribution) Philippines, Halmahera, Sulu Islands, Palawan, Natuna, Borneo, and Celebes.

\section{Family Dicruridae}

51. Dicrurus leucopaeus stigmatops (Sharpe) 1우, Aug. 15, Kundasang

(Note) I collected this montane species in Kundasang that was about 5000 feet high, and observed this species on the to? o? a house in Kota Belud. Iris red, feet and bill black. Culmen $22 \mathrm{~mm}$, wing $118 \mathrm{~mm}$, tail $116 \mathrm{~mm}$, tarsus $16 \mathrm{~mm}$.

(Distribution) Mountains of N. Borneo

*52. Dicrurus paradiseus Linnaeus Pandasan

(Note) I observed this species only once in the jungle of Pandasan.

(Distribution) India, S. E. Asia.

\section{Family Oriolidae}

*53. Oriolus xanthonotus Horsfield Kota Belud

(Note) I observed this species on trees near the rest house of Kota Belud.

(Distribution) S. E. Asia

Bibliography:

1 Peters (J. L): Check-list of Birds of the World 1931-1969.

2 Smythies (B. E): Birds of Borneo 1968 
3 Stuart Baker (E. C): Fauna of Bitish India. Birds 1922-1930

4 Ripley (D) : A synopsis of the Birds of India and Pakistan 1961

5 Smythies (B. E): The Birds of Burma 1953

6 Kuroda $(\mathrm{N})$ : Birds of island of Java

7 Lekagul (B): Birds Guide of Thailand 1968

8 Kobayashi (K): Birds of Japan in Natural Colours 1956

9 Miyamoto ( $T$ ): About Birds in Java Island Hyogo Biology Vol. 4 No. 3-4, 1962

10 Miyamoto (T): About Birds in Formosa Island Hyogo Biology Vol. 5, No. 5, 1968

11 Miyamoto (T): About Birds near Bombay in India Hyogo Biology Vol. 6, No. 2,1970 